[Chem. Pharm. Bull.

35( 7 )2656-2660(1987)

\title{
Nitration of 3-Acylindoles in the Presence of Metal MeCN Solvates and Synthesis of the Antibiotic Alkaloid Chuangxinmycin
}

\author{
Masayuki Murase, TAKeshi KoIKe, YuKari Moriya, \\ and SeISHO ToBinaga*
}

Showa College of Pharmaceutical Sciences, Tsurumaki, Setagaya-ku, Tokyo 154, Japan

(Received November 18, 1986)

\begin{abstract}
Nitration of 3-acylindoles in the presence of $\mathrm{MeCN}$ solvates of $\mathrm{Cu}^{2+}, \mathrm{Al}^{3+}$, and $\mathrm{Fe}^{2+}$ salts yielded 3-nitroindole, 4-nitro- and 6-nitro-3-acylindoles, of which 3-acetyl-4-nitroindole was subsequently transformed into dehydrochuangxinmycin (7), the dehydro derivative of the antibiotic alkaloid chuangxinmycin (2).
\end{abstract}

Keywords_-nitration; 3-acylindole; metal $\mathrm{MeCN}$ solvate; 3-acetyl-4-nitroindole; synthesis; chuangxinmycin

Considerable interest has been focused on the direct C-4 substitution reaction of indoles in connection with the synthesis of C-4-substituted indole alkaloids, including the ergot family alkaloids (e.g. lysergic acid (1)) and chuangxinmycin (2). Although several direct C-4 substitution reactions of indole ${ }^{1-4)}$ have been developed, direct nitration or halogenation at C-4 of indoles has not been achieved to date. For example, nitration of 3-formyl- or 3acetylindole in acidic media gave only a few percent of the 4-nitro derivative. ${ }^{5,6)}$ This paper deals with nitration of 3-acylindoles in the presence of metal acetonitrile (AN) solvates, $\mathrm{Cu}(\mathrm{AN})_{6}\left(\mathrm{ClO}_{4}\right)_{2}, \mathrm{Al}(\mathrm{AN})_{6}\left(\mathrm{ClO}_{4}\right)_{3}$, and $\mathrm{Fe}(\mathrm{AN})_{6}\left(\mathrm{BF}_{4}\right)_{2}$, to give the 4-nitro derivatives in significant yields. We also describe the subsequent transformation of the 3-acetyl-4nitroindole (3) to dehydrochuangxinmycin (7), the dehydro derivative of the unique antibiotic alkaloid chuangxinmycin (2).

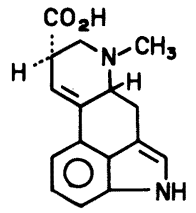

1

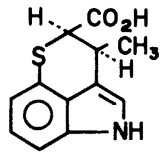

2

Chart 1

\section{Nitration of 3-Acylindoles in the Presence of Metal MeCN Solvates}

The solvates in $\mathrm{AN}, \mathrm{Cu}(\mathrm{AN})_{6}\left(\mathrm{ClO}_{4}\right)_{2}, \mathrm{Al}(\mathrm{AN})_{6}\left(\mathrm{ClO}_{4}\right)_{3}$, and $\mathrm{Fe}(\mathrm{AN})_{6}\left(\mathrm{BF}_{4}\right)_{2}$, were prepared from the corresponding metal salt hydrates, $\mathrm{Cu}\left(\mathrm{ClO}_{4}\right)_{2} \cdot 6 \mathrm{H}_{2} \mathrm{O}, \mathrm{Al}\left(\mathrm{ClO}_{4}\right)_{3} \cdot 8 \mathrm{H}_{2} \mathrm{O}$, and $\mathrm{Fe}\left(\mathrm{BF}_{4}\right)_{2} \cdot 6 \mathrm{H}_{2} \mathrm{O}$, in $\mathrm{AN}$ by the addition of 6 or $8 \mathrm{~mol}$ of $\mathrm{Ac}_{2} \mathrm{O}$ to remove water. ${ }^{7}$ Nitrations of 3-acetylindole and 3-formylindole (3-indolecarbaldehyde) were carried out with $99 \% \mathrm{HNO}_{3}$ in the presence of the metal solvates in AN. The results are shown in Table I.

On the other hand, nitration of 3-acylindoles in the presence of Lewis acids, namely, $\mathrm{BF}_{3}$, $\mathrm{BCl}_{3}, \mathrm{AlCl}_{3}$, etc., in $\mathrm{AN}$, glyme or $\mathrm{CH}_{2} \mathrm{Cl}_{2}$ afforded only the 6-nitro derivatives as the main 
TABLE I. Nitration of 3-Acylindoles in the Presence of Metal MeCN Solvates

\begin{tabular}{|c|c|c|c|c|c|c|c|c|}
\hline \multirow{2}{*}{ Entry } & \multirow{2}{*}{ Substituent } & \multirow{2}{*}{ Catalyst } & \multicolumn{4}{|c|}{ Position of nitration, yield $(\%)$} & \multirow{2}{*}{$\begin{array}{c}\text { Time } \\
\text { (h) }\end{array}$} & \multirow{2}{*}{$\begin{array}{r}\text { Temp. } \\
\left({ }^{\circ} \mathrm{C}\right)\end{array}$} \\
\hline & & & $3-$ & $4-$ & 6- & Recover & & \\
\hline 1 & 3-Ac & A & 38.4 & 20.5 & 25.4 & - & 1 & 15 \\
\hline 2 & 3-Ac & B & 16.1 & 12.3 & 24.3 & 7.2 & 2 & 13 \\
\hline 3 & 3-Ac & $\mathrm{C}$ & 28.2 & 20.8 & 31.9 & - & 3.5 & 15 \\
\hline 4 & 3-Formyl & A & 21.7 & 19.1 & 19.3 & 3.4 & 19 & 13 \\
\hline 5 & 3-Formyl & B & 9.6 & 15.5 & 22.1 & 18.4 & 4 & 5 \\
\hline 6 & 3-Formyl & $\mathrm{C}$ & 21.9 & 5.9 & 21.8 & 29.8 & 24 & 15 \\
\hline
\end{tabular}

Meial complex: A, $\mathrm{Cu}(\mathrm{AN})_{6}\left(\mathrm{ClO}_{4}\right)_{2} ; \mathrm{B}, \mathrm{Al}(\mathrm{AN})_{8}\left(\mathrm{ClO}_{4}\right)_{3} ; \mathrm{C}, \mathrm{Fe}(\mathrm{AN})_{6}\left(\mathrm{BF}_{4}\right)_{2}$.

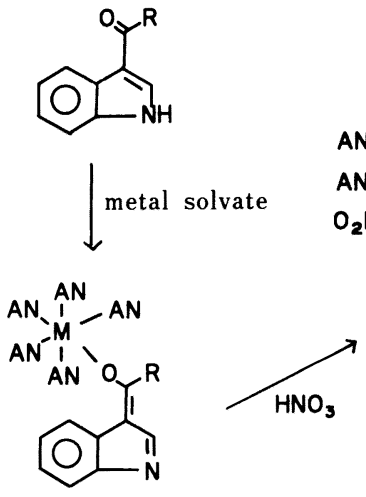

complex A
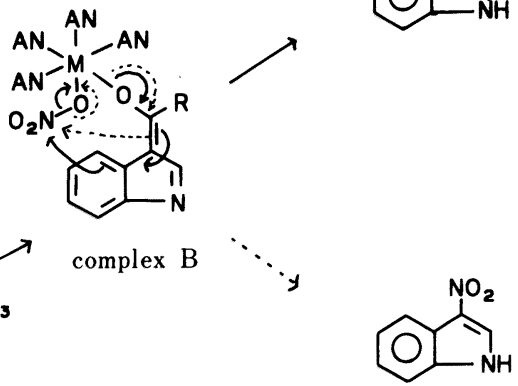

Chart 2

product. The formation of significant amounts of 4-nitro derivatives and 3-nitroindole in the nitration of 3-acylindoles in the presence of the metal AN solvates may depend on the involvement of complexes such as A and B, whose existence is supported by the color changes from light blue (complex A) to deep green (complex B) during the course of the reaction and by the solubility changes of 3-acylindoles (3-acylindoles are less soluble in AN without the metal solvates).

\section{A New Synthesis of Methyl Dehydrochuangxinmycin}

Chuangxinmycin (a new kind of mycin) (2) is an antibiotic alkaloid having a unique indole skeleton, isolated from the microorganism Actinoplanes tsinanensis $\mathrm{n}$. $\mathrm{sp}$. in China. This compound is known to be active in vitro against a number of gram-positive and gramnegative bacteria and to be active in vivo in mice against Escherichia coli and Shigella dysenteria infections. Preliminary clinical results have shown that chuangxinmycin is effective in the treatment of septicemia and urinary and biliary infections caused by $E$. coli. ${ }^{8,9)}$ The structure of 2 was confirmed by X-ray crystallography ${ }^{10)}$ and syntheses. ${ }^{11,12)}$ We synthesized dehydrochuangxinmycin (7) from 3-acetyl-4-nitroindole (3) prepared by means of the above reaction.

The 4-amino derivative 4 prepared by reduction of 3 by catalytic hydrogenation or with $\mathrm{TiCl}_{3}$, was transformed to the 4-iodo compound $5^{13)}$ through the diazonium salt. Novel displacement of iodine with thioacetate to give the methyl thioacetate 6 was performed by treatment of the iodide with methyl thioglycolate in pyridine-methanol in $95 \%$ yield. 


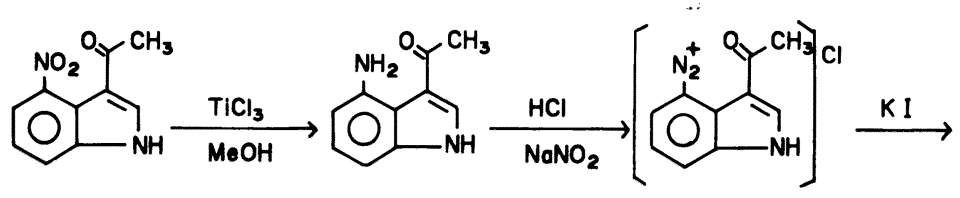

3

4

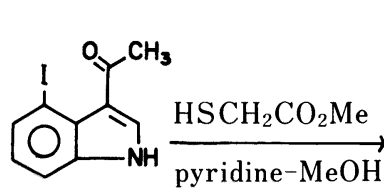

5

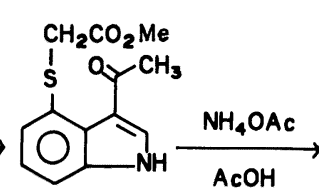

6

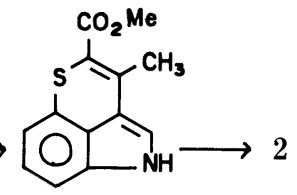

7

Chart 3

Treatment of the thioacetate $\mathbf{6}$ with ammonium acetate in $\mathrm{AcOH}$ afforded dehydrochuangxinmycin (7) in $93 \%$ yield. All physical data of the product 7 were identical with those given previously. ${ }^{12)}$ Thus, the formal synthesis of chuangxinmycin (2) by a new route was attained.

\section{Experimental}

All melting points are uncorrected. Infrared (IR) spectra were recorded with a Hitachi 260-10 spectrometer, proton nuclear magnetic resonance $\left({ }^{1} \mathrm{H}-\mathrm{NMR}\right)$ spectra with a JEOL JNM-FX 100 or JEOL JNM-GX 270 spectrometer (with tetramethylsilane as an internal standard in $\mathrm{CDCl}_{3}, \mathrm{CD}_{3} \mathrm{COCD}_{3}$ and dimethyl sulfoxide (DMSO) $-d_{6}$ solution) and mass spectra (MS) with a JEOL JMS-d 300 spectrometer. Wako Silica Gel C-200 (200 mesh) and Merck Kieselgel $60 \mathrm{~F}_{254}$ were used for column chromatography and thin layer chromatography (TLC), respectively.

Nitrations of 3-Acetylindole in the Presence of Metal AN Solvates- Method A: The solvate, $\mathrm{Cu}(\mathrm{AN})_{6}\left(\mathrm{ClO}_{4}\right)_{2}$, was prepared by the addition of $7.14 \mathrm{~g}(70 \mathrm{mmol})$ of $\mathrm{Ac}_{2} \mathrm{O}$ to a solution of $3.70 \mathrm{~g}(10 \mathrm{mmol})$ of $\mathrm{Cu}\left(\mathrm{ClO}_{4}\right)_{2} \cdot 6 \mathrm{H}_{2} \mathrm{O}$ in AN $(29 \mathrm{ml})$ at room temperature, and the mixture was stirred for $30 \mathrm{~min}$. Then $1.59 \mathrm{~g}(10 \mathrm{mmol})$ of acetylindole was added and the mixture was stirred at room temperature for $30 \mathrm{~min}$. At that time, the color of the solution changed from light blue to dark green. To the above mixture, $756 \mathrm{mg}$ of $\mathrm{HNO}_{3}(99 \%)$ in $\mathrm{AN}(1 \mathrm{ml})$ was added very slowly at $15^{\circ} \mathrm{C}$ with stirring and the whole was stirred at the same temperature for $1 \mathrm{~h}$. The precipitates (3-acetyl-6-nitroindole) were separated by filtration. The filtrate was poured into water and extracted with AcOEt. The organic layer was washed with sat. $\mathrm{NaHCO}_{3}$ and brine. The AcOEt layer was dried and concentrated under vacuum. The residue was subjected to dry silica gel column chromatography. The first eluate with AcOEt-hexane $(1: 1)$ gave $623 \mathrm{mg}(38.4 \%)$ of 3-nitroindole as light yellow needles (AcOEt-benzene), mp 213-214 ${ }^{\circ} \mathrm{C}$. NMR $\left(\mathrm{CD}_{3} \mathrm{COCD}_{3}\right) \delta: 7.32-7.42(2 \mathrm{H}, \mathrm{m}$, aromatic $\mathrm{H}), 7.59-7.65(1 \mathrm{H}, \mathrm{m}$, aromatic $\mathrm{H}), 8.16-8.23(1 \mathrm{H}, \mathrm{m}$, aromatic $\mathrm{H}), 8.49(1 \mathrm{H}, \mathrm{s}, \mathrm{C}-2 \mathrm{H})$, and $11.54(1 \mathrm{H}$, br s, NH) ${ }^{5 a)}$ The second eluate with the same solvent was combined with the previous precipitates and recrystallized from acetone to give $519 \mathrm{mg}(25.4 \%)$ of 3-acetyl-6-nitroindole as brown crystals, mp $340-342{ }^{\circ} \mathrm{C}$. NMR $\left(\mathrm{CD}_{3} \mathrm{COCD}_{3}\right) \delta: 2.53\left(3 \mathrm{H}, \mathrm{s}, \mathrm{COCH}_{3}\right), 8.115(1 \mathrm{H}, \mathrm{dd}, J=9.28,1.95 \mathrm{~Hz}, \mathrm{C}-5 \mathrm{H}), 8.43-8.58(3 \mathrm{H}, \mathrm{m}$, aromatic $\mathrm{H})$, $11.53(1 \mathrm{H}, \mathrm{br} \mathrm{s}, \mathrm{NH}){ }^{5 a)}$ The third eluate afforded $420 \mathrm{mg}(20.5 \%)$ of 3-acetyl-4-nitroindole as yellow needles (AcOEt), mp 229-230 ${ }^{\circ} \mathrm{C}$. NMR $\left(\mathrm{CD}_{3} \mathrm{COCD}_{3}\right) \delta: 2.49\left(3 \mathrm{H}, \mathrm{s}, \mathrm{COCH}_{3}\right), 7.39(1 \mathrm{H}, \mathrm{t}, J=7.81 \mathrm{~Hz}, \mathrm{C}-6 \mathrm{H}), 7.605(1 \mathrm{H}, \mathrm{dd}, J=7.8$, $1 \mathrm{~Hz}, \mathrm{C}-7 \mathrm{H}), 7.85(1 \mathrm{H}, \mathrm{dd}, J=7.8,1 \mathrm{~Hz}, \mathrm{C}-5 \mathrm{H}), 8.43(1 \mathrm{H}, \mathrm{d}, J=2.9 \mathrm{~Hz}, \mathrm{C}-2 \mathrm{H}), 11.53(1 \mathrm{H}, \mathrm{br} \mathrm{s}, \mathrm{NH}) .{ }^{5 a}$

Method B: The solvate, $\mathrm{Al}(\mathrm{AN})_{6}\left(\mathrm{ClO}_{4}\right)_{3}$, was prepared with $4.69 \mathrm{~g}(10 \mathrm{mmol})$ of $\mathrm{Al}\left(\mathrm{ClO}_{4}\right)_{3} \cdot 8 \mathrm{H}_{2} \mathrm{O}$ and $9.18 \mathrm{~g}$ $(90 \mathrm{mmol})$ of $\mathrm{Ac}_{2} \mathrm{O}$ in $29 \mathrm{ml}$ of $\mathrm{AN}$. Nitration of $1.59 \mathrm{~g}(10 \mathrm{mmol})$ of 3-acetylindole was carried out with $756 \mathrm{mg}$ of $99 \% \mathrm{HNO}_{3}$ in $\mathrm{AN}(1 \mathrm{ml})$ at $13^{\circ} \mathrm{C}$ for $2 \mathrm{~h}$. The reaction mixture was worked up as described in method $\mathrm{A}$, and the residue obtained was purified according to method A to give $261 \mathrm{mg}(16.1 \%)$ of 3-nitroindole, $114 \mathrm{mg}(7.2 \%)$ of 3acetylindole, $496 \mathrm{mg}(24.3 \%)$ of 3-acetyl-6-nitroindole, and $252 \mathrm{mg} \mathrm{(12.3 \% )} \mathrm{of} \mathrm{3-acetyl-4-nitroindole.}$

Method C: The solvate, $\mathrm{Fe}(\mathrm{AN})_{6}\left(\mathrm{BF}_{4}\right)_{2}$, was prepared with $3.38 \mathrm{~g}(10 \mathrm{mmol})$ of $\mathrm{Fe}\left(\mathrm{BF}_{4}\right)_{2} \cdot 6 \mathrm{H}_{2} \mathrm{O}$ and $7.14 \mathrm{~g}$ $(70 \mathrm{mmol})$ of $\mathrm{Ac}_{2} \mathrm{O}$ in $29 \mathrm{ml}$ of AN. Reaction of $1.59 \mathrm{~g}$ of 3-acetylindole in the presence of the solvate with $756 \mathrm{mg}$ of $99 \% \mathrm{HNO}_{3}$ in $\mathrm{AN}(1 \mathrm{ml})$ was carried out at $15{ }^{\circ} \mathrm{C}$ for $3.5 \mathrm{~h}$. The mixture was worked up as described in method $\mathrm{A}$, and the residue obtained was purified according to method A to give $475 \mathrm{mg}(28.2 \%)$ of 3-nitroindole, $652 \mathrm{mg}(31.6 \%)$ of 3-acetyl-6-nitroindole, and $426 \mathrm{mg}(20.8 \%)$ of 3-acetyl-4-nitroindole.

Nitration of 3-Indolecarbaldehyde in the Presence of Metal AN Solvates - Method A: 3-Indolecarbaldehyde 
$(1.45 \mathrm{~g}, 10 \mathrm{mmol})$ was added to a solution of the solvate, $\mathrm{Cu}(\mathrm{AN})_{6}\left(\mathrm{ClO}_{4}\right)_{2}$ [prepared from $3.70 \mathrm{~g}(10 \mathrm{mmol})$ of $\mathrm{Cu}\left(\mathrm{ClO}_{4}\right)_{2} \cdot 6 \mathrm{H}_{2} \mathrm{O}$ and $7.14 \mathrm{~g}(70 \mathrm{mmol})$ of $\left.\mathrm{Ac}_{2} \mathrm{O}\right]$, in $29 \mathrm{ml}$ of $\mathrm{AN}$ as described for the reaction of 3-acetylindole above, and the mixture was stirred at room temperature for $30 \mathrm{~min}$. Then $756 \mathrm{mg}$ of $99 \% \mathrm{HNO}_{3}$ in $\mathrm{AN}(1 \mathrm{ml})$ was added very slowly at $13{ }^{\circ} \mathrm{C}$ and the whole was stirred at room temperature for $19 \mathrm{~h}$. The reaction mixture was poured into water and extracted with AcOEt. The AcOEt layer was washed with sat. $\mathrm{NaHCO}_{3}$ and brine. The organic layer was dried and concentrated under a vacuum. The residue was subjected to dry silica gel chromatography. The first eluate with AcOEt-hexane (1.5:2) gave $352 \mathrm{mg}(21.7 \%)$ of 3-nitroindole as light yellow needles (AcOEt-benzene). The second eluate gave $49 \mathrm{mg}(3.4 \%)$ of 3-indolecarbaldehyde. The third eluate with the same solvent afforded $368 \mathrm{mg}(19.3 \%)$ of 6-nitro-3-indolecarbaldehyde as yellow crystals (acetone), mp 302-304 ${ }^{\circ} \mathrm{C}$ (dec.). NMR (DMSO- $\left.d_{6}\right) \delta: 8.09(1 \mathrm{H}$, dd, $J=8.79,2 \mathrm{~Hz}, \mathrm{C}-5 \mathrm{H}), 8.25(1 \mathrm{H}, \mathrm{d}, J=8.79 \mathrm{~Hz}, \mathrm{C}-4 \mathrm{H}), 8.42(1 \mathrm{H}, \mathrm{d}, J=2 \mathrm{~Hz}, \mathrm{C}-7 \mathrm{H}), 8.65(1 \mathrm{H}, \mathrm{s}, \mathrm{C}-2 \mathrm{H}), 10.03(1 \mathrm{H}$, $\mathrm{s}, \mathrm{CHO}), 12.65\left(1 \mathrm{H}\right.$, brs, NH) ${ }^{5 b)}$ The 4 th eluate with the same solvent yielded $364 \mathrm{mg}(19.1 \%)$ of $4-$ nitro-3indolecarbaldehyde as orange needles (AcOEt-hexane), mp $190-192^{\circ} \mathrm{C}$. NMR $\left(\mathrm{CD}_{3} \mathrm{COCD}_{3}\right) \delta: 7.49(1 \mathrm{H}, \mathrm{t}$, $J=8.0 \mathrm{~Hz}, \mathrm{C}-6 \mathrm{H}), 7.96(1 \mathrm{H}, \mathrm{dd}, J=8.0,0.7 \mathrm{~Hz}, \mathrm{C}-7 \mathrm{H}), 8.00(1 \mathrm{H}, \mathrm{dd}, J=8.0,0.7 \mathrm{~Hz}, \mathrm{C}-5 \mathrm{H}), 8.43(1 \mathrm{H}, \mathrm{s}, \mathrm{C}-2 \mathrm{H})$, $10.29(1 \mathrm{H}, \mathrm{s}, \mathrm{CHO}), 11.84(1 \mathrm{H}, \mathrm{s}, \mathrm{NH}){ }^{5 b)}$

Method $\mathrm{B}$ : The solvate, $\mathrm{Al}(\mathrm{AN})_{6}\left(\mathrm{ClO}_{4}\right)_{3}$, was prepared from $4.69 \mathrm{~g}(10 \mathrm{mmol})$ of $\mathrm{Al}\left(\mathrm{ClO}_{4}\right)_{3} \cdot 8 \mathrm{H}_{2} \mathrm{O}$ and $9.18 \mathrm{~g}$ $(90 \mathrm{mmol})$ of $\mathrm{Ac}_{2} \mathrm{O}$ in $29 \mathrm{ml}$ of $\mathrm{AN}$. Reaction of $1.45 \mathrm{~g}(10 \mathrm{mmol})$ of 3 -indolecarbaldehyde in the presence of the solvate was carried out with $756 \mathrm{mg}$ of $99 \% \mathrm{HNO}_{3}$ in $\mathrm{AN}(1 \mathrm{ml})$ at $5{ }^{\circ} \mathrm{C}$ for $4 \mathrm{~h}$. The reaction mixture was worked up as described in method $\mathrm{A}$ and the residue obtained was purified according to method $\mathrm{A}$ to give $156 \mathrm{mg}(9.6 \%)$ of $3-$ nitroindole, $267 \mathrm{mg}(18.4 \%)$ of 3-indolecarbaldehyde, $420 \mathrm{mg}(22.1 \%)$ of 6-nitro-3-indolecarbaldehyde, and $295 \mathrm{mg}$ $(15.5 \%)$ of 4-nitro-3-indolecarbaldehyde.

Method $\mathrm{C}$ : The solvate, $\mathrm{Fe}(\mathrm{AN})_{6}\left(\mathrm{BF}_{4}\right)_{2}$, was prepared with $3.38 \mathrm{~g}(10 \mathrm{mmol})$ of $\mathrm{Fe}\left(\mathrm{BF}_{4}\right)_{2} \cdot 6 \mathrm{H}_{2} \mathrm{O}$ and $7.14 \mathrm{~g}$ ( $70 \mathrm{mmol})$ of $\mathrm{Ac}_{2} \mathrm{O}$ in $\mathrm{AN}(29 \mathrm{ml})$. Nitration of $1.45 \mathrm{~g}(10 \mathrm{mmol})$ of 3-indolecarbaldehyde with $765 \mathrm{mg} \mathrm{of} 99 \% \mathrm{HNO}_{3}$ in $\mathrm{AN}(1 \mathrm{ml})$ in the presence of the solvate was carried out at $15^{\circ} \mathrm{C}$ for $24 \mathrm{~h}$. The reaction mixture was worked up as described in method A, and purified according to method A to give $355 \mathrm{mg}(21.9 \%)$ of 3-nitroindole, $430 \mathrm{mg}(29.8 \%)$ of 3 -indolecarbaldehyde, $415 \mathrm{mg}(21.8 \%)$ of 6-nitro-3-indolecarbaldehyde, and $113 \mathrm{mg}(5.9 \%)$ of 4 -nitro-3indolecarbaldehyde.

3-Acetyl-4-aminoindole (4) A $31.8 \mathrm{ml}$ portion of $\mathrm{TiCl}_{3}$ solution $(17-19 \%$ ) was added at once to a suspension of $1.17 \mathrm{~g}$ of 3-acetyl-4-nitroindole $(3)$ in $\mathrm{MeOH}(8 \mathrm{ml})$ and the mixture was stirred at room temperature for $1.5 \mathrm{~h}$. The crystalline precipitates were separated by filtration, and washed with $23 \% \mathrm{HCl}$. The precipitates were dissolved in hot water, and then the solution was basified with sat. $\mathrm{NaHCO}_{3}$. The basic solution was extracted with AcOEt. The organic layer was dried and concentrated. The residue was recrystallized from $\mathrm{MeOH}$ to give $980 \mathrm{mg}(91.0 \%)$ of 4 as yellow crystals, mp $232-234^{\circ} \mathrm{C}\left(\mathrm{dec}\right.$ ). IR (Nujol) $\mathrm{cm}^{-1}: 3425,3280,1590$. NMR $\left(\mathrm{CD}_{3} \mathrm{COCD}_{3}\right) \delta: 2.48(3 \mathrm{H}, \mathrm{s}$, $\left.-\mathrm{COCH}_{3}\right), 5.6\left(2 \mathrm{H}, \mathrm{br}, \mathrm{NH}_{2}\right), 6.32(1 \mathrm{H}, \mathrm{dd}, J=7.8,1 \mathrm{~Hz}, \mathrm{C}-5 \mathrm{H}$ or C-7 H), $6.62(1 \mathrm{H}, \mathrm{dd}, J=8.3,1 \mathrm{~Hz}, \mathrm{C}-5 \mathrm{H}$ or C-7 H), $6.92(1 \mathrm{H}, \mathrm{dd}, J=8.3,7.8 \mathrm{~Hz}, \mathrm{C}-6 \mathrm{H}), 8.09(1 \mathrm{H}, \mathrm{d}, J=3.4 \mathrm{~Hz}, \mathrm{C}-2 \mathrm{H}), 10.8(1 \mathrm{H}, \mathrm{br} \mathrm{s}$, indole NH). MS $m / z$ : Calcd for $\mathrm{C}_{10} \mathrm{H}_{10} \mathrm{~N}_{2} \mathrm{O}\left(\mathrm{M}^{+}\right)$: 174.0793. Found: 174.0811 .

3-Acetyl-4-iodoindole (5) - A solution of $369 \mathrm{mg}$ of $\mathrm{NaNO}_{2}$ in water $(9 \mathrm{ml})$ was added slowly to a solution of $422.8 \mathrm{mg}$ of 4 in $2 \mathrm{~N} \mathrm{HCl}$ with stirring at $0^{\circ} \mathrm{C}$. To the above diazonium salt solution, a solution of $25 \mathrm{~g} \mathrm{KI}$ in water $\left(18 \mathrm{ml}\right.$ ) was added with stirring at $0{ }^{\circ} \mathrm{C}$, and the whole was stirred at room temperature for $1 \mathrm{~h}$ and then at $85^{\circ} \mathrm{C}$ for $10 \mathrm{~min}$. After cooling, the mixture was extracted with AcOEt. The organic layer was washed with $5 \% \mathrm{Na}_{2} \mathrm{~S}_{2} \mathrm{O}_{3}$ and brine. The AcOEt layer was dried and concentrated. The residue was subjected to dry silica gel chromatography, and the eluate with AcOEt-hexane $(1: 1.5)$ gave $505 \mathrm{mg}(73 \%)$ of 5 as colorless needles $(\mathrm{MeOH}), \mathrm{mp} 215-218^{\circ} \mathrm{C}(\mathrm{dec}$.) (lit. mp 204-206 $\left.{ }^{\circ} \mathrm{C}(\mathrm{dec}).\right){ }^{13)} \mathrm{IR}$ (Nujol) $\mathrm{cm}^{-1}: 3140,1640 . \mathrm{NMR}\left(\mathrm{CD}_{3} \mathrm{COCD}_{3}\right) \delta: 2.50\left(3 \mathrm{H}, \mathrm{s}, \mathrm{COCH}_{3}\right), 6.95(1 \mathrm{H}$, dd, $J=8.3,7.32 \mathrm{~Hz}, \mathrm{C}-6 \mathrm{H}), 7.56(1 \mathrm{H}, \mathrm{dd}, J=8.3,1 \mathrm{~Hz}, \mathrm{C}-5 \mathrm{H}$ or C-7 H), $7.76(1 \mathrm{H}, \mathrm{dd}, J=7.32,1 \mathrm{~Hz}, \mathrm{C}-5 \mathrm{H}$ or C-7

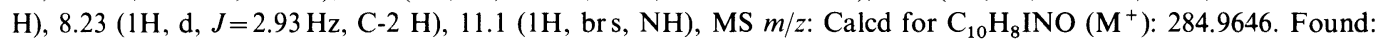
284.9645. Anal. Calcd for $\mathrm{C}_{10} \mathrm{H}_{8} \mathrm{INO}$ : C, 42.13; H, 2.83; N, 4.91. Found: C, 42.20; H, 2.93; N, 4.62.

Methyl [(3-Acetyl-4-indolyl)thio] acetate (6) - A solution of $28.5 \mathrm{mg}$ of 5, 34 mg of methyl thioglycolate and $26.1 \mathrm{mg}$ of pyridine in $\mathrm{MeOH}(1 \mathrm{ml})$ was heated at $90^{\circ} \mathrm{C}$ under a nitrogen atmosphere for $48 \mathrm{~h}$. Water was added to the mixture, and the whole was extracted with AcOEt. The organic layer was washed with dil. $\mathrm{HCl}, \mathrm{sat}^{\mathrm{NaHCO}} \mathrm{Na}_{3}$, and brine. The AcOEt layer was dried and concentrated. The residue was recrystallized from benzene to give $26 \mathrm{mg}$ $(95 \%)$ of 6 as colorless needles, mp $140-141.5^{\circ} \mathrm{C} . \mathrm{NMR}\left(\mathrm{CDCl}_{3}\right) \delta: 2.48\left(3 \mathrm{H}, \mathrm{s}, \mathrm{COCH}_{3}\right), 3.72\left(3 \mathrm{H}, \mathrm{s}, \mathrm{CO}_{2} \mathrm{CH}_{3}\right)$, $3.78\left(2 \mathrm{H}, \mathrm{s},-\mathrm{SCH}_{2}-\right), 7.08-7.19(3 \mathrm{H}, \mathrm{m}$, aromatic $\mathrm{H}), 7.69(1 \mathrm{H}, \mathrm{d}, \mathrm{C}-2 \mathrm{H}), 9.47(1 \mathrm{H}, \mathrm{br}, \mathrm{NH})$. Ethyl [(3-acetyl-4indolyl)thio]acetate was prepared by similar reaction of 5 and ethyl thioglycolate: $\mathrm{mp} 140-141^{\circ} \mathrm{C}(\mathrm{MeOH})$. IR (Nujol) $\mathrm{cm}^{-1}: 3160,1719,1619 . \mathrm{NMR}\left(\mathrm{CD}_{3} \mathrm{COCD}_{3}\right) \delta: 1.18\left(3 \mathrm{H}, \mathrm{t}, J=7.1 \mathrm{~Hz}, \mathrm{COCH}_{2} \mathrm{CH}_{3}\right), 2.49\left(3 \mathrm{H}, \mathrm{s}, \mathrm{COCH}_{3}\right)$, $3.74\left(2 \mathrm{H}, \mathrm{s},-\mathrm{SCH}_{2}-\right), 4.11\left(2 \mathrm{H}, \mathrm{q}, J=7.1 \mathrm{~Hz}, \mathrm{COCH}_{2} \mathrm{CH}_{3}\right), 7.14(1 \mathrm{H}, \mathrm{dd}, J=7,2 \mathrm{~Hz}, \mathrm{C}-5 \mathrm{H}$ or C-7 H), $7.18(1 \mathrm{H}, \mathrm{t}$, $J=7 \mathrm{~Hz}, \mathrm{C}-6 \mathrm{H}), 7.32(1 \mathrm{H}, \mathrm{dd}, J=7,2 \mathrm{~Hz}, \mathrm{C}-5 \mathrm{H}$ or C-7 H), $8.20(1 \mathrm{H}, \mathrm{d}, J=3.2 \mathrm{~Hz}, \mathrm{C}-2 \mathrm{H}), 11.05(1 \mathrm{H}, \mathrm{br}$ s, NH). MS $m / z$ : Calcd for $\mathrm{C}_{14} \mathrm{H}_{15} \mathrm{NO}_{3} \mathrm{~S}\left(\mathrm{M}^{+}\right): 277.077$. Found: 277.0763 .

Dehydrochuangxinmycin Methyl Ester (7)_-A mixture of $108 \mathrm{mg}$ of 6, $144 \mathrm{mg}$ of ammonium acetate monohydrate, and $277 \mathrm{mg}$ of $\mathrm{AcOH}$ in benzene $(8 \mathrm{ml})$ was heated at $110^{\circ} \mathrm{C}$ for $15 \mathrm{~h}$ under a nitrogen atmosphere. Water was added to the mixture, and the whole was extracted with AcOEt. The organic layer was washed with sat. $\mathrm{NaHCO}_{3}$ and brine. The AcOEt layer was dried and concentrated. The residue was recrystallized from benzene to 
give $93 \mathrm{mg}(93 \%)$ of methyl dehydrochuangxinmycin (7) as yellow needles, mp 167-168 ${ }^{\circ} \mathrm{C}^{12 a)} \mathrm{NMR}\left(\mathrm{CDCl}_{3}\right) \delta: 2.34$ $\left(3 \mathrm{H}, \mathrm{s}, \mathrm{CH}_{3}\right), 3.81\left(3 \mathrm{H}, \mathrm{s}, \mathrm{CO}_{2} \mathrm{CH}_{3}\right), 6.51-6.94(4 \mathrm{H}, \mathrm{m}$, aromatic $\mathrm{H}), 7.91(1 \mathrm{H}$, br s, NH). Anal. Calcd for $\mathrm{C}_{13} \mathrm{H}_{11} \mathrm{NO}_{2} \mathrm{~S}: \mathrm{C}, 63.67 ; \mathrm{H}, 4.52 ; \mathrm{N}, 5.71$. Found: $\mathrm{C}, 63.63 ; \mathrm{H}, 4.68 ; \mathrm{N}, 5.44$. Ethyl dehydrochuangxinmycin was prepared by similar reaction of ethyl [(3-acetyl-4-indolyl)thio]acetate: $\mathrm{mp} 183-185^{\circ} \mathrm{C}(\mathrm{MeOH})$. IR ( $\mathrm{Nujol} \mathrm{cm}^{-1}$ : 3250, 1640. NMR $\left(\mathrm{CD}_{3} \mathrm{COCD}_{3}\right) \delta: 1.31\left(3 \mathrm{H}, \mathrm{t}, J=7 \mathrm{~Hz}, \mathrm{CO}_{2} \mathrm{CH}_{2} \mathrm{CH}_{3}\right), 2.32\left(3 \mathrm{H}, \mathrm{s}, \mathrm{CH}_{3}\right), 4.22(2 \mathrm{H}, \mathrm{q}, J=7 \mathrm{~Hz}$, $\left.\mathrm{CO}_{2} \mathrm{CH}_{2} \mathrm{CH}_{3}\right), 6.46(1 \mathrm{H}, \mathrm{dd}, J=7,1.1 \mathrm{~Hz}, \mathrm{C}-8 \mathrm{H}$ or $\mathrm{C}-10 \mathrm{H}), 6.81-6.91(2 \mathrm{H}, \mathrm{m}$, aromatic $\mathrm{H}), 7.25(1 \mathrm{H}, \mathrm{d}, J=2.5 \mathrm{~Hz}$, C-2 H), $10.32\left(1 \mathrm{H}\right.$, br s, NH). Anal. Calcd for $\mathrm{C}_{14} \mathrm{H}_{13} \mathrm{NO}_{2} \mathrm{~S}: \mathrm{C}, 64.84 ; \mathrm{H}, 5.05 ; \mathrm{N}, 5.40$. Found: C, 64.64; H, 5.16: N, 5.19 .

\section{References and Notes}

1) G. Nechvatal and D. A. Widdowson, J. Chem. Soc., Chem. Commun., 1982, 467.

2) A. G. M. Barett, D. Dauzonne, and D. J. Williams, J. Chem. Soc., Chem. Commun., 1982, 636; A. G. M. Barett, D. Dauzonne, I. A. Oneil, and A. Renand, J. Org. Chem., 49, 4409 (1984).

3) M. Somei, T. Hasegawa, and C. Kaneko, Heterocycles, 20, 1983 (1983).

4) O. Yonemitsu, P. Cerutti, and B. Witkop, J. Am. Chem. Soc., 88, 3941 (1966).

5) a) W. E. Noland and K. R. Rush, J. Org. Chem., 31, 70 (1966); b) A. Da. Settimo, Gazz. Chim. Ital., 92, 150 (1962).

6) Very recently, it was reported that nitration of 3-carbomethoxyindole with $\mathrm{HNO}_{3}$ in $\mathrm{AcOH}$ at $60{ }^{\circ} \mathrm{C}$ afforded the corresponding 4-nitro and 6-nitro derivatives, each in 30\% yield. S. Nakatsuka, T. Masuda, O. Asano, T. Teramae, and T. Goto, Tetrahedron Lett., 27, 4327 (1986).

7) E. Kotani, S. Kobayashi, Y. Ishii, and S. Tobinaga, Chem. Pharm. Bull., 32, 4281 (1984).

8) H.-T. Liang, H.-D. Hsu, C.-P. Chang, H.-E. Ku, and W.-S. Wang, Hua Hsueh Huseh Pao, 34, 129 (1976) [Chem. Abstr., 87, 165948z (1977)].

9) L. Wang and T. Qi, Kangshengsu, 11, 338 (1986) [Chem. Abstr., 105, 168773q (1986)].

10) H.-C. Hsu, M.-C. Shao, C.-Y. Chang, K.-P. Li, K.-C. Chou, and Y.-C. Tang, K'o Hsueh T'ung Pao, 25, 350 (1980) [Chem. Abstr., 93, 2678w (1980)].

11) C.-P. Chang, H.-D. Hsu, L.-C. Huang, Y.-C. Lin, H.-S. Li, C.-L. Yu, and C.-L. Chao, Hua Hsueh Hsueh Pao, 34, 133 (1976) [Chem. Abstr., 88, 62309h (1976)].

12) A. P. Kozikowski and M. N. Greco, J. Am. Chem. Soc., 102, 1165 (1980); A. P. Kozikowski, M. N. Greco, and J. P. Springer, ibid., 104, 7622 (1982).

13) R. A. Hollins, L. A. Colnago, V. M. Salim, and M. C. Seidl, J. Heterocycl. Chem., 16, 993 (1979). 